\title{
陽イオン交換樹脂を用いた血中尿素の固相抽出並びに 高速液体クロマトグラフィー
}

\author{
新谷 英晴 ${ }^{\circledR *}$, 井上 剛 ${ }^{* *}$ \\ (1994 年 4 月 13 日受理)
}

\section{1 緒言}

健常人の場合, タンパク質の最終産物として尿素サイ クルで生成する尿素はじんから尿中に排せつされる．尿 毒症患者ではじん機能低下のため尿中に排せつされるべ き尿素が血中に蓄積し, 諸蔵器の機能低下, 尿素による 尿素サイクルのフィードバック阻害, 尿素によるタンパ ク質の変性等が生じる。それゆえ血中尿素を減少させる ことは不可欠である. そのため人工透析等を行って尿素 を含む尿毒症成分の除去が行われている.

ところで透析後血中尿素がどれほど定量的に除去され たかを知る必要がある，そのためには効率的な血中尿素 の定量法が不可欠である.

現在臨床機器として血並びに尿中尿素はウレア一ゼを 固定したアンモニア選択電極で測定されているが，本方 法では内因性のアンモニアとの分別分析が不可能であ る.

現在まで固定化ウレアーゼを用いて血中尿素を分析し た例は報告されている1) -4). しかし，それらの方法に は様々な欠点がある.

まず内因性アンモニアと尿素との分別に煩雑さを伴う こと, 固定化ウレア一ゼの経時的劣化ゆえ分析ごとに検 量線を取り直す煩雑さがあること, ポストカラムの場合 には溶離液の $\mathrm{pH}$ がウレアーゼの至適 $\mathrm{pH}$ である 7.4 に限定されること，この溶離液（pH 7.4）条件では一級 アミノ基を有する尿素はテイリングを起こしやすい欠点 があること等である. ウレアーゼで処理後生成したアン モニアの検出には低感度で選択性のない refractive index (RI) 以外の検出方法がないため高感度分析には支障を きたす。

* 厚生省国立衛生試験所：158 東京都世田谷区上用賀 1-18-1

** ユニフレックス(株)：277 千葉県柏市高田 537-1
そこで固定化ウレアーゼカラムを用いずに血中尿素を 固相抽出（solid phase extraction, SPE）で血中きょう雑 物から分離し分析することを試みた。血中尿素の SPE の報告がなかった理由として, 尿素が血中きょう雑物と 同時に溶出するためその分離に困難をきたしたためと思 われる．著者らはそれらを克服し，血中きょう雑物と十 分分離し, 再現性の良い SPE 並びに HPLC 条件が確立 できたので報告する.

\section{2 実験条件並びに試料}

\section{2・1 HPLC 条件}

カラム: 三菱化成 MCI GEL CK08S（強酸性陽イオ ン交換樹脂 $(\mathrm{Na}$ 型) ) $4.6 \times 150 \mathrm{~mm}$; 溶離液: $1 \mathrm{mM}$ 塩 酸水溶液; 流量: $1 \mathrm{ml} / \mathrm{min}$ (HPLC 装置日本分光 PU-980); 検出: UV $200 \mathrm{~nm}$ (UV 検出器日本分光 PU-970); 試料注入量: $20 \mu \mathrm{l}$; カラム温度: $35^{\circ} \mathrm{C}$; 尿素保 持時間: 6 分

\section{$2 \cdot 2$ SPE 条件}

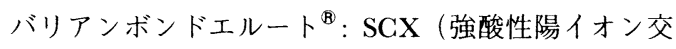
換樹脂 ( $\mathbf{H}$ 型)); 樹脂量: $500 \mathrm{mg}$; 容積: $2.8 \mathrm{ml}$; コンデ イショニング: メタノール $3 \mathrm{ml}$ その後水 $3 \mathrm{ml}$ (流量 3 $\mathrm{ml} / \mathrm{min}$ ); 試料量: 血清 $1 \mathrm{ml}$; 洗净: 水 $1 \mathrm{ml}$ (流量 3 $\mathrm{ml} / \mathrm{min}$ ); 溶出: $5 \%$ リン酸水溶液 $4 \mathrm{ml}$ (流量 1 $\mathrm{ml} / \mathrm{min}$ )

コンディショニング, 洗浄並びに溶出は真空ポンプを 用いて行った ${ }^{5) 6)}$.

\section{$2 \cdot 3$ 試 料}

尿素 (和光純薬工業製), 血清 (関東化学製)

\section{4 限外沪過, 遠心分離}

これらは文献 5）6）に示したものを用いた。 


\section{3 結果並びに考察}

\section{$3 \cdot 1$ HPLC による尿素の検量線}

尿素濃度とピーク面積との相関並びに回帰直線はそれ ぞれ $r=1.0, Y=841.5 X-13584.9$, であり，良好な直線 性が得られた。検量線は $600 \mu \mathrm{g} / \mathrm{ml}$ を超えて更に直線 性を示したが，内因性尿素濃度（平均 $328.0 \pm 21.4$ $\mu \mathrm{g} / \mathrm{ml}, \mathrm{RSD}=6.5 \%, n=4)$ はこの検量線濃度範囲にあ るためこれ以上の検量線の直線性は不要である.

\section{$3 \cdot 2$ SPE}

SPE の手法は常法に従った ${ }^{5) 6)}$. 血清尿素保持のため SPE カラムとして順相, 逆相, イオン交換系等種々の 樹脂を検討した。その結果一番保持力のよかった強酸性 陽イオン交換カラムを用いることにした.

洗浄液として水を用い, その液量を $0 \sim 4 \mathrm{ml}$ と変化 させた. 0 2 ml までは SPE カラムに保持された尿素 は溶出されなかった. $3 \mathrm{ml}$ を超えると溶出された. そ れゆえ実験条件としては $1 \mathrm{ml}$ に設定した。

洗浄後 SPE カラムに保持された尿素の溶出には $5 \%$ リン酸水溶液を用い，以下の溶出条件を検討した１）1 $\mathrm{ml}$ を 4 回，2） $2 \mathrm{ml}$ を 2 回並びに 3） $4 \mathrm{ml}$ を 1 回であ る。それぞれの回収率は $96.0,96.8,93.7 \%$ であり良好 な回収率が得られた。すなわち計 $4 \mathrm{ml} て ゙$ て溶出すればほ ぼ完全に回収されることが分かった。

次に内因性尿素を含む血清に対して尿素標準液（濃度 $1 \mathrm{mg} / \mathrm{ml}$ ) を 9:1 の割合で添加し回収率を求めたとこ ろ $101.9 \%, \mathrm{RSD}=2.2 \%(n=4)$ とほぼ満足な結果が得 られた。

次に血清タンパク質と結合している尿素と遊離尿素と
を分別定量するため排除限界 10000 ダルトンの限外沃 過セルロース膜を用い $1767 \mathrm{~g}$ で遠心分離して沪液を得 た。試料としては血清に尿素標準液（濃度 $1 \mathrm{mg} / \mathrm{ml}$ ) を 9:1の割合で添加した血清を用いた. その理論尿素 量と沪液を SPE 並びに HPLC で定量した結果得られた 尿素量との比較から沪液中には $104.5 \%$ の尿素が回収さ れたことが分かった。

この実験で血清タンパク質と結合している尿素はほと んどなく，血清中にはほとんどが遊離型尿素で存在する と推定される.

以上の結果血中尿素を血中きょう雑物と十分分離でき る HPLC 条件並びに血中尿素を十分再現性よく回収で きる SPE 条件が確立できた。

自動化された SPE とオートインジェクタ一並びに自 動化された HPLC と組み合わせれば，本条件で自動化 臨床検査機器の開発が可能であり, 現在臨床機器として 専ら用いられているアンモニアイオン選択電極よりはる かに選択性並びに感度の点で優れた臨床機器になるもの と期待される.

\section{文献}

1) H. Shintani, H. Suzuki: "Bioinstrumentation and Biosensors", Edited by D. L. Wise, p. 181 (1990), (Marcel Dekker, Inc., New York).

2) H. Shintani: J. Chromatogr., 378, 95 (1986).

3) H. Shintani, S. Ube: J. Chromatogr., 344, 145 (1985).

4) H. Shintani, A. Wojcik: "Enzyme Reaction Detection in Liquid Chromatography", Edited by S. K. Lam, in press (1994), (Blakie and Son, Inc., New York).

5) H. Shintani: J. Anal. Toxicol., 15, 198 (1991).

6) H. Shintani: J. Anal. Toxicol., 17, 73 (1993).

Determination of blood urea using cation exchange column solid phase extraction combined with HPLC. Hideharu SHINTANI and Takashi Inoue ${ }^{* *}\left({ }^{*}\right.$ National Institute of Health Sciences, 1-18-1, Kamiyoga, Setagaya-ku, Tokyo 158; ${ }^{* *}$ Uniflex Co. Ltd., 537-1, Takada, Kashiwa-shi, Chiba 277)

To determine blood urea accurately in uremia patients, a simple analytical procedure combining a solid phase extraction (SPE) and high performance liquid chromatography (HPLC) was studied. SPE was performed using Bond Elute SCX (resin weight, $500 \mathrm{mg}$; resin volume, $2.8 \mathrm{ml}$ ) which was conditioned with $3 \mathrm{ml}$ of methanol followed by $3 \mathrm{ml}$ of water and eluted with $4 \mathrm{ml}$ of $5 \%$ phosphate solution. For HPLC, MCIgel CK08S $(4.6 \times 150 \mathrm{~mm})$ was eluted with $1 \mathrm{mM} \mathrm{HCl} \mathrm{at} \mathrm{a} \mathrm{flow} \mathrm{rate} \mathrm{of} 1 \mathrm{ml} / \mathrm{min}$ and column temperature at $35^{\circ} \mathrm{C}$ with detection at $200 \mathrm{~nm}$. By comparing ultrafiltrated blood urea and native blood urea, the blood urea from the HPLC chromatogram was found to be 
completely free of blood admixtures and almost free of blood protein. We concluded that the current clinical method of blood urea determination which uses an ammonia selective electrode could be replaced by our method which is more selective and provides more accurate and reliable data for diagnosis.

(Received April 13, 1994)

\section{Keyword phrases}

solid phase extraction; strong cation exchanger; HPLC; urea; uremia. 